\title{
高高度飛翔体による準天頂衛星測位システムの補強について*1 Augmentation of Quasi-Zenith Satellite Positioning System Using High Altitude Platforms Systems (HAPS)
}

\author{
辻 井 利 昭*2 $\cdot$ 張 替 正 敏*2 \\ Toshiaki TsujII and Masatoshi Harigae
}

Key Words : Quasi-Zenith Satellite, Positioning System, HAPS, Pseudolite, GPS

\begin{abstract}
Recently, some feasibility studies on a regional positioning system using the quasi-zenith satellites and the geostationary satellites have been conducted in Japan. However, the geometry of this system seems to be unsatisfactory in terms of the positioning accuracy in north-south direction. In this paper, an augmented satellite positioning system by the High Altitude Platform Systems (HAPS) is proposed since the flexibility of the HAPS location is effective to improve the geometry of satellite positioning system. The improved positioning performance of the augmented system is also demonstrated.
\end{abstract}

\section{1. は じめ に}

米国によって開発，運用されている GPS は簡便で高精度 な航法測位システムとして, 日本でも自動車や船舶の航法 をはじめ航空宇宙や地球科学の分野で広く利用されている. 米国以外ではロシアが GPS と独立の衛星航法システムと して GLONASS を運用しており，欧州では GALILEO が 開発中である．また日本でも，衛星測位システムが国民生 活に重要な社会インフラであることから, 静止衛星や準天 頂衛星を用いた独自の測位システムの研究が進められてい る1).このシステムは, サービス領域を日本と近隣諸国に 限ることにより GPS 等の大域測位システムに比べて 3 分 の 1 以下の衛星数で構成可能なこと, 準天頂衛星が常に高 仰角に観測できることから建造物の多い都市部でも常時信 号が受信できること等の利点がある．

一方, 高度約 $20 \mathrm{~km}$ に滞在する成層圏プラットフォーム (Stratospheric Platform, SPF) の研究開発か㳄米や日本, 中国, 韓国で進行している. 韦の主目的は通信・放送や地 球観測であるが, 航法測位への利用も提案されている ${ }^{2 \sim 5)}$. SPF や高高度無人機などの高高度飛翔体 (High Altitude Platforms Systems, HAPS) を測位に利用した場合，炎の 配置の自由度が大きいこと, 打ち上げのコストが衛星に比 べて低いこと, 回収が容易なため機器の更新が容易なこと 等の利点がある. 本論文では, HAPS が準天頂衛星や静止 衛星からなる測位システムの測位精度を向上させるのに有 効であることを示し, 衛星と HAPS で構成される日本独自 の測位システムを提案する (第 1 図) .

\footnotetext{
*1 C) 2003 日本航空宇宙学会

平成 15 年 5 月 29 日原稿受理

*2 独立行政法人航空宇宙技術研究所
}

\section{2. 衛星および HAPS の配置と測位誤差指標( GDOP)}

日本および近隣諸国を対象とする衛星測位システムの衛 星軌道配置は樣々なものが考えられるが，本論文では準天 頂衛星 3 機, 静止衛星 5 機の計 8 機で構成されるシステム を例とする ${ }^{1)}$.第 2 図で, 5 個の丸印は静止衛星 , 実線は準 天頂衛星の東京から見た方位および仰角を示す . 3 機の準天 頂衛星は同じ軌道を通るため図では重なって見えるが，位 相間隔が 120 度で配置されており地上からは常時 2 機が観 測できる .この衛星配置は一見して南側に偏っており，南北 方向の測位精度が東西方向に比べて劣ると推測される . 測 位精度は衛星の配置によって決まる GDOP (Geometrical Dilution of Precision) という指標を用いて見積もること ができるが，GPS では通常上下方向の測位精度が悪いので， 水平方向の指標 HDOP と上下方向の指標 VDOP に分ける ことがある．さらに，精密測量では南北方向，東西方向で の測位精度が問題になることがあり，光れぞれの成分に分 けて示すことがある（以下光れ光れ NDOP , EDOP と表 す). たとえば, 橋梁の変位を精密に測定する場合に南北方 向の精度が不足するため, 兴の方向に GPS と同樣な信号 を発信するシュードライトを設置して測位精度を向上させ る研究も行われている6).

第 3 図に 8 機の衛星で構成される測位システムにおける 観測衛星数, NDOP , EDOP , VDOP を示す (細線). 測 位誤差は DOP 值に測距誤差を乗じて見積もられるため， DOP 值が大きいほど測位誤差が大きい . 本システムでは , 衛星配置からの推測通り NDOP は EDOP の約 75\%増と なっている．关こで, 南北方向の非対称性を緩和するため に高度 $20 \mathrm{~km}$ の HAPS を北側に配備することを考える .こ こでは, 第 2 図のように仰角 30 度, 方位角 45 度および 315 度に配置した (四角印). 兴の場合の DOP 值を第 3 図 


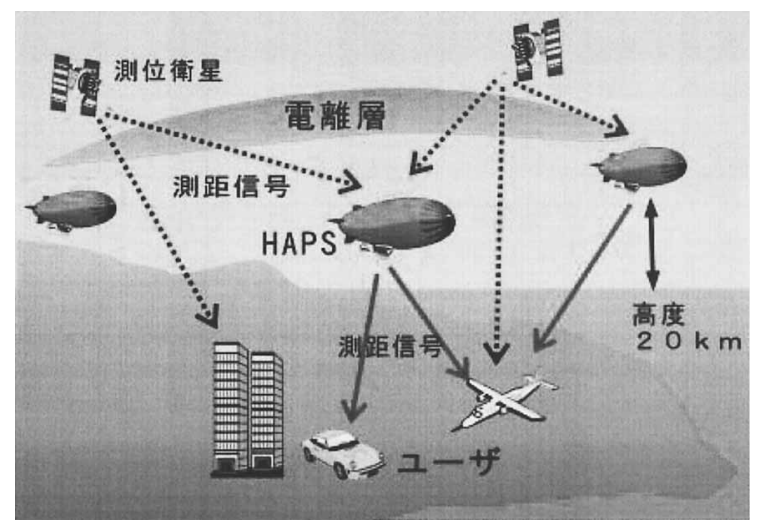

第 1 図 衛星と HAPS による航法測位システム

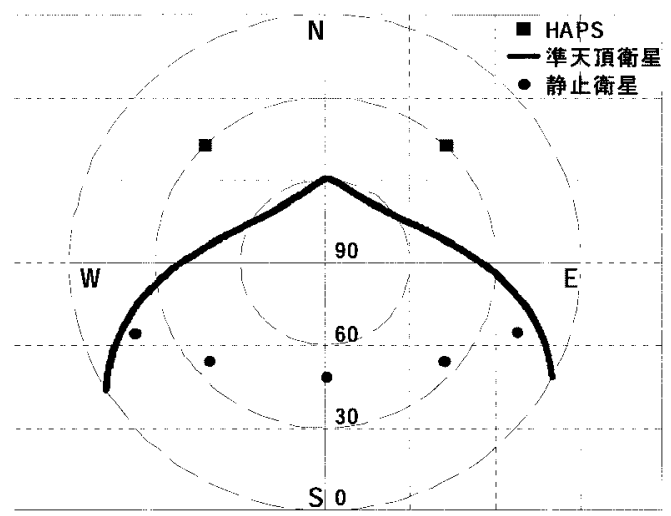

第 2 図 準天頂衛星，静止衛星，および HAPS の方位と仰角
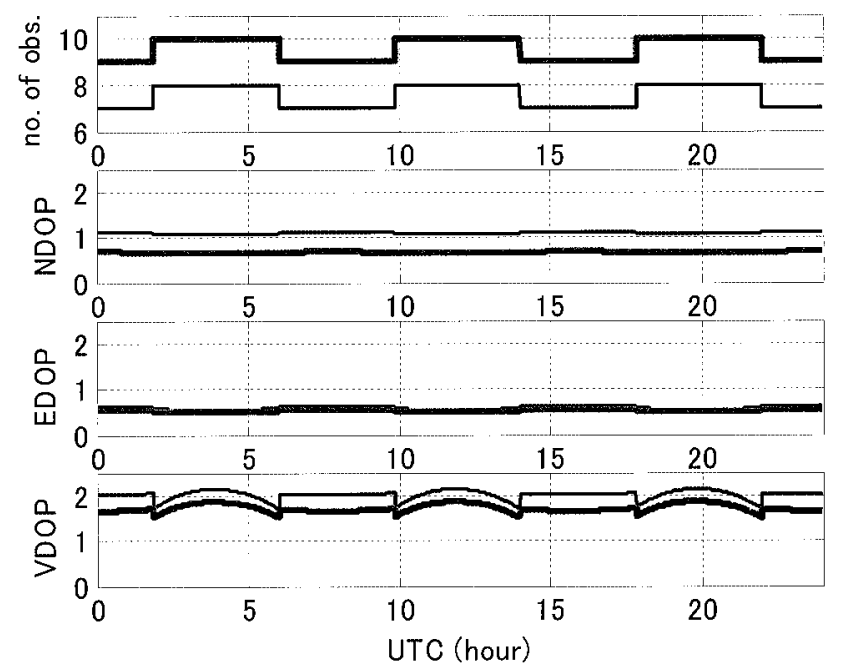

第 3 図観測機数 (細線 : 衛星のみ, 太線 : 衛星および HAPS) と測 位誤差の指標（南北，東西，上下方向）

に太線で示す．NDOP が約 35\%改善し，EDOPに近い値 となった . また, VDOP も改善されている.ただし DOP 值で正確に評価できるのは誤差が正規分布に従う場合であ り，代表的な測位誤差の電離層遅延や対流圏遅延誤差には， ランダム誤差に加えて系統的な成分があるので次項で検討 する .
第 1 表 GPS および HAPS の誤差源と単独測位誤差

\begin{tabular}{lcc}
\hline \multirow{2}{*}{ 誤差源 } & \multicolumn{2}{c}{$1 \sigma$ 誤差 $(\mathrm{m})$} \\
\cline { 2 - 3 } & GPS & HAPS \\
\hline 軌道歴 & 2.1 & 0.1 \\
衛星時計 & 2.1 & 2.1 \\
電離層遅延 & 4.0 & 0 \\
大気迤延 & 0.7 & 0.7 \\
マルチパス & 1.4 & 1.4 \\
受信機ノイズ & 0.5 & 0.5 \\
\hline 測距誤差 & 5.3 & 2.7 \\
\hline 測位誤差 $(1 \sigma)$ & 15.9 & 8.1 \\
GDOP $=3$ の場合 & & \\
\hline
\end{tabular}

\section{3. 系統的測距誤差と測位誤差}

GPS 測距信号における誤差源を第 1 表にまとめる ${ }^{7)}$.こ こで, 受信機時計や衛星時計の誤差は差分航法により除去 できる .またマルチパス誤差や受信機ノイズは高機能レシー バやアンテナを用いることで軽減可能である．さらに電離 層遅延は，二周波受信機を用いれば消去できるので，多く の応用分野で対流圈遅延が最大誤差源とされている. 弚こ で, 本論文では系統的測距誤差の例として対流圈遅延を取 り上げ, 弚の測位誤差への影響を検討する.第 1 表では比較 のため HAPS における誤差量の見積もりも行った . HAPS は電離層よりも下に位置するため, 電離層遅延量を含まな いことが大きな特徵である. 軌道暦は地上に設置した受信 機で観測した HAPS からの測距信号を用いていわゆる逆 GPS 法により高精度に生成される ${ }^{3)}$. 逆 GPS 法の地上実 験では精度数 $\mathrm{cm}$ の精密軌道暦の作成に成功しており ${ }^{3)}$, 高 高度でもデシメートルレベルが详成できると考えている．

対流圈遅延量は気圧, 気温, 湿度等の気象データをもとに 推定できるが,気象観測装置をもたない移動局等では標準值 (気圧 $1013.25 \mathrm{mbar}$, 気温 $18^{\circ} \mathrm{C}$, 相対湿度 $50 \%$ ) や, 日 時と観測地の座標から平均的な気象値を計算できる大域モ デルを用いる . 例えば UNB4 モデル8) を用いると，2003 年 8 月 1 日 12 時 (JST) の東京では, 気圧 $1013.5 \mathrm{mbar}$, 気 温 $29^{\circ} \mathrm{C}$, 相対湿度 $26 \%$ となり，天頂遅延量は $2.54 \mathrm{~m}$ とな る.これに対し, 非常に高温多湿な状態 (気圧 $1013.5 \mathrm{mbar}$ ， 気温 $34^{\circ} \mathrm{C}$, 相対湿度 $100 \%$ ）を想定すると天頂遅延量は $2.81 \mathrm{~m}$ となってモデル值よりも $27 \mathrm{~cm}$ 大きくなる.本論 文ではこの值を天頂遅延推定誤差とし, 各衛星, HAPSに 対する遅延量は仰角にのみ依存すると仮定して天頂遅延に $1 / \sin (e l)$ ( $e l$ : 仰角) を乗じて計算し，結果的に生ずる測 位誤差を見積もった . 第 4 图に, 対流圏遅延に起因する測 位誤差 (南北，東西，上下方向）を示す . 細線は衛星のみの 場合で，東西方向がほぼゼロに対して南北方向に約 $15 \mathrm{~cm}$ のバイアス誤差が生じており，衛星配置の非対称性の影響 と考えられる，一方，HAPS を二機使用した場合には南北， 東西両方向で測位誤差はほぼゼ口になっており, 配置の対称 化の効果が大きいことがわかる．すなわち，HAPS の使用 でランダム誤差は縮小されるのに対し，系統誤差は大部分 相殺されており，全体的な測位誤差の見積もりには通常行 われている DOP 值の評価のみでは不十分なことがわかる . 


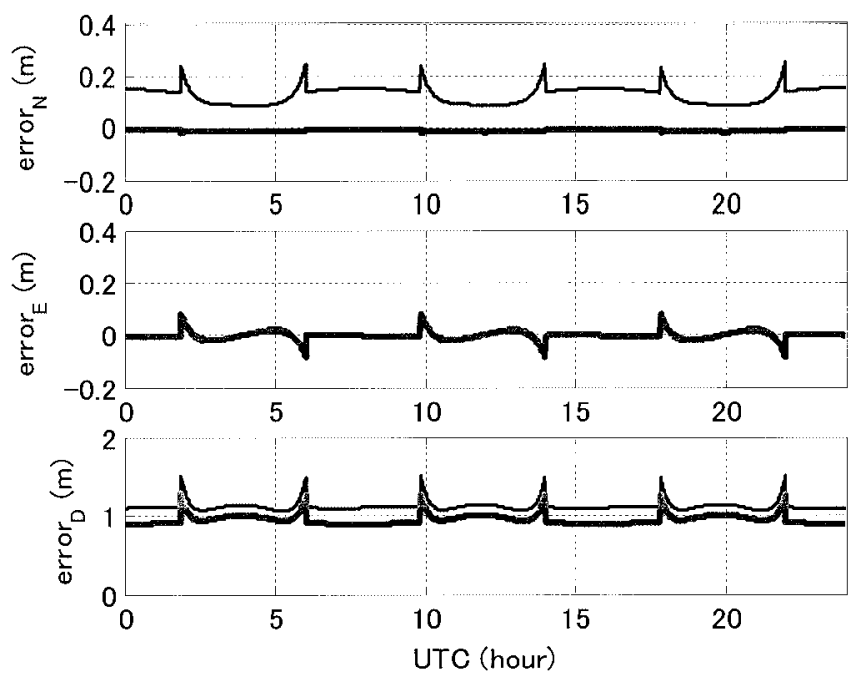

第 4 図 対流圏遅延による測位誤差
4. ま と め

準天頂衛星および静止衛星で構成される測位システムは， 衛星軌道の性質上ユーザの南側に偏っており，南北方向の 測位精度の劣化が予想される.乥こでHAPS を北側に配置 して測位システム全体の対称化を行い測位精度の変化を見 積もった ·光の結果 , ランダム誤差の影響を示す DOP は 南北方向で約 35\%改善した．また，系統的誤差である対流 圏遅延に起因する測位誤差は, HAPS を使用することによ り南北方向で大幅に縮小されることが明らかとなった .

HAPS は衛星と異なり配置の自由度が大きいため，測位
システムの幾何学的性質の改善に有効である . 準天頂衛星 等と複合することにより, 日本独自の高精度な領域測位シ ステムを構成することができると考えられ, 今後研究開発 を進めていく計画である .

\section{参 考 文 献}

1) 河野 功 : 準天頂衛星と静止衛星による衛星測位システム, 電子 情報通信学会論文誌 B ，J84-B (2001)，pp. 2092-2100.

2) 辻井利昭, Rizos, C., Wang, J., Dai, L., 張替正敏 : 成層圏プラッ トフォームを用いた疑似 GPS 衛星による航法測位サービスにつ いて , 日本航空宇宙学会論文集 , 50 (2002), pp. 36-39.

3) Tsujii, T., Harigae, M., Barnes, J., Wang, J. and Rizos, C.: Experiments of Inverted Pseudolite Positioning for AirshipBased GPS Augmentation System, 15th Int. Tech. Meeting of the Satellite Division of the U.S. Inst. of Navigation, Portland, Oregon, 2002, pp. 1689-1695.

4) Dovis, F., Mulassano, P. and Dumville, M.: The Stratolite Concept: Design of a Stratospheric Pseudo-Satellite for Galileo, 15th Int. Tech. Meeting of the Satellite Division of the U.S. Inst. of Navigation, Portland, Oregon, 2002, pp. 347-355.

5) 辻 宏之, 三浦 龍, 張間康秋：ヘリコプタ上のアレーアンテナ を使用した無線局位置推定実験, 第 4 回成層圏プラットフォーム ワークショップ講演前刷集 , 2003, pp. 233-239.

6) Meng, X., Roberts, G., Dodson, E. and Cosser, E.: The Use of Pseudolites to Augment GPS Data for Bridge Deflection Measurements, 15th Int. Tech. Meeting of the Satellite Division of the U.S. Inst. of Navigation, Portland, Oregon, 2002, pp. 851-862.

7）安田明生 : GPS と炎の応用, GPS シンポジウム 2001 テキスト, 2001, pp. 193-216.

8) Collins, J. P., Langley, R. B. and LaMance, J.: Limiting Factors in Tropospheric Propagation Delay Error Modelling for GPS Airborne Navigation. 52nd ION Annual Meeting, Cambridge, Mass, 1996, pp. 519-528. 